\title{
Studi Fenomenologi Pengalaman Perubahan Citra Tubuh pada Klien Kelemahan Pasca Sroke di RSUP Dr M Djamil Padang
}

\author{
Novi Herawati \\ Program Studi Keperawatan Solok Jurusan Keperawatan \\ Politeknik Kesehatan Kemenkes Padang \\ ophie_cut@yahoo.com
}

\begin{abstract}
Stroke is a clinical syndrome of neurological deficits, which can cause death and weakness. This weakness will impact on the client's body image changes after stroke. The research purpose is to explore client experiences pasca stroke weakness at changes in body image. Descriptive phenomenological qualitative research design with in-depth interviews to 7 pasca stroke with weakness clients undergoing outpatient neurology polyclinic of Dr. M. Djamil Padang City Hospital. Data were gathered in interview recording and field note form, then transcribed and analized by Colaizzi's techniques. This study identified eight themes included the decrease in function and changes in the body's ability, emotional conflict to changes in the body, changes in social activities, increased ability at changes in body image, external support at changes in body image, coping strategies used for changes in body image, family support for healing and expectations for recovery of the body. Results showed weakness affects the physical, psychological and social that potential to cause psychosocial problems. Coping strategies that used, still might have a risk of maladaptive behavior. It can be a condition of the psychosocial needs nursing care and therapy psychiatric nursing can be given proper. It is expected nurse as nursing care providers can improve the role and function as counselors and nursing care providers with caring.
\end{abstract}

Keyword: Changes in body image, Pasca Stroke, Weakness

\begin{abstract}
Abstrak: Stroke merupakan sindrom klinis berupa defisit neurologis, yang dapat mengakibatkan kematian dan kelemahan. Kelemahan ini akan berdampak pada perubahan citra tubuh klien pasca stroke. Tujuan penelitian mengeksplorasi gambaran pengalaman klien kelemahan pasca stroke menghadapi perubahan citra tubuh. Desain penelitian kualitatif deskriptif fenomenologi dengan metode wawancara mendalam terhadap 7 klien pasca stroke dengan kelemahan yang menjalani rawat jalan di poliklinik neurologi RS Dr. M. Djamil Padang. Data berupa rekaman wawancara dan catatan lapangan, dibuat transkrip dan analisis menggunakan tekhnik Colaizzi. Hasil penelitian didapatkan delapan tema, yaitu penurunan fungsi dan perubahan kemampuan tubuh, konflik emosi terhadap perubahan tubuh, perubahan aktifitas sosial, peningkatan kemampuan diri menghadapi perubahan citra tubuh, dukungan eksternal menghadapi perubahan citra tubuh, strategi koping menghadapi perubahan citra tubuh, dukungan keluarga terhadap kesembuhan dan harapan terhadap pemulihan kondisi tubuh. Hasil penelitian menunjukkan kelemahan berdampak terhadap fisik, psikologi dan sosial yang berpotensi menimbulkan masalah psikososial. Penggunaan strategi koping juga masih ada yang beresiko perilaku maladaptif. Hal ini dapat menjadi gambaran kebutuhan asuhan keperawatan psikososial dan dapat diberikan terapi keperawatan jiwa yang tepat. Diharapkan perawat sebagai pemberi pelayanan keperawatan dapat meningkatkan peran dan fungsinya sebagai konselor dan pemberi yankep yang caring.
\end{abstract}

Kata Kunci: Perubahan citra tubuh, pasca stroke, kelemahan

Stroke merupakan sindrom klinis yang timbulnya mendadak, cepat, berupa defisit neurologis yang berlangsung 24 jam atau lebih, bisa juga langsung menimbulkan kematian yang disebabkan gangguan peredaran darah otak non traumatik. Stroke merupakan penyebab kematian nomor tiga di dunia setelah penyakit jantung dan kanker. Di Indonesia, menurut hasil Riset Kesehatan Dasar tahun 2007 stroke justru merupakan penyebab kematian utama, dimana Sumatera Barat memiliki prevalensi stroke 10,6\%.

Berbagai masalah yang mungkin dialami oleh pasien pasca stroke diantaranya kelumpuhan atau kelemahan, gangguan keseimbangan, gangguan berbicara atau berkomunikasi, gangguan menelan dan gangguan memori (Mulyatsih, 2008). Kelumpuhan ataupun kelemahan yang dialami individu stroke akan berdampak 
pada kemampuannya dalam melakukan kegiatan kesehariannya bahkan kebutuhan yang sangat dasar sekalipun, seperti: makan, berpakaian, berkemih, kebersihan diri, dan lainnya. Ketergantungan individu dengan stroke terhadap orang lain dalam melakukan aktifitas sehari-hari berdampak terhadap kondisi psikologis pasien stroke.

Perubahan citra tubuh yang dialami klien pasca stroke memberikan pengaruh secara signifikan terhadap kehidupannya dimana terjadi penurunan yang signifikan terhadap semua tindakan dan perilakunya yang juga berdampak besar pada harga dirinya (Keppel dan Crowe, 2000). Perubahan citra tubuh pada penderita stroke dengan berbagai respon yang ditimbulkannya akan berimbas pada terjadinya gangguan citra tubuh. Gangguan citra tubuh adalah distorsi persepsi, perilaku dan kognitif yang berhubungan dengan perubahan ukuran atau bentuk tubuh yang terjadi pada diri seseorang (Pimenta, et al, 2009). Gangguan citra tubuh merupakan salah satu masalah psikososial yang dapat menjadi patologis pada individu dengan stroke bila tidak ditangani dengan tepat. Salah satunya adalah depresi yang sering terjadi pada pasien stroke (Alspach, 2013; Waluyo, 2009). Untuk itu perlu perhatian dan tindakan preventif guna mencegah terjadinya gangguan jiwa.

\section{METODE}

Penelitian ini mengenai pengalaman perubahan citra tubuh yang dialami klien kelemahan pasca stroke. Desain penelitian menggunakan kualitatif dengan pendekatan deskriptif fenomenologi. Metode deskriptif fenomenologi yaitu penelitian kualitatif yang mengekplorasi pengalaman secara langsung melalui interaksi antara peneliti dan peserta penelitian (partisipan) dalam penelitian dan mendeskripsikan tiap-tiap bagian dari fenomena yang ada secara bebas dari fenomena yang belum tergali (Spiegerlberg, 1975 dalam Streubert \& Carpenter, 2003).

Partisipan pada penelitian ini adalah klien pasca stroke dengan kelemahan yang menjalani rawat jalan di poliklinik neurologi RS Dr. M. Djamil Padang, yang berjumlah 7 orang. Tempat pengambilan datanya di salah satu ruangan yang kondusif yang disiapkan oleh peneliti dan kepala ruangan di ruangan poliklinik neurologi RS Dr. M. Djamil Padang. Namun ada partisipan ingin memilih tempat sendiri di lingkungan RS selama tempat tersebut dapat memberikan rasa nyaman kepada partisipan maka peneliti memenuhinya. Pengumpulan data berlangsung Mei-Juni 2013.

Pengumpulan data dilakukan dengan wawancara mendalam dilakukan selama 5090 menit. Analisis data penelitian menggunakan langkah-langkah analisis data dari Colaizzi, (1978) dalam Polit \& Beck (2006) dengan membaca semua transkrip, membaca setiap transkrip dan menemukan pernyataan signifikan, memberikan makna dan kategori-kategori yang sesuai, mengelompokkan kategori-kategori yang sama untuk memunculkan tema, mengintegrasikan deskripsi sesuai paparan dari partisipan terkait tema-tema, merumuskan deskripsi lengkap, menyerahkan kepada partisipan hasil temuan yang diperoleh sebagai langkah validasi data. 
Partisipan berjumlah tujuh orang, rincian karakteristik dapat dilihat pada tabel 1 berikut:

\begin{tabular}{|l|l|l|l|l|l|l|}
\hline Kode & Usia & Agama & $\begin{array}{l}\text { Status } \\
\text { Perkawinan }\end{array}$ & $\begin{array}{l}\text { Pendidikan } \\
\text { Terakhir }\end{array}$ & Pekerjaan & Kelemahan yang dialami \\
\hline P1 & 58 tahun & Islam & Menikah & SMA & Pensiunan & kaki dan tangan kiri \\
\hline P2 & 57 tahun & Islam & Menikah & SMA & Pensiunan & kaki dan tangan kiri \\
\hline P3 & 57 tahun & Islam & Menikah & SMA & Wiraswasta & kaki dan tangan kanan \\
\hline P4 & 57 tahun & Islam & Menikah & Diploma 3 & Guru & kaki dan tangan kiri \\
\hline P5 & 50 tahun & Islam & Menikah & SMP & Tani & kaki dan tangan kiri \\
\hline P6 & 57 tahun & Islam & Menikah & SMA & Buruh & kaki dan tangan kiri \\
\hline P7 & 58 tahun & Islam & Menikah & SD & Tani & kaki dan tangan kiri \\
\hline
\end{tabular}

Didapatkan gambaran pengalaman perubahan citra tubuh klien dengan kelemahan pasca stroke, meliputi:

1. Gambaran respon dari pengalaman perubahan citra tubuh pada klien kelemahan pasca stroke

a. Penurunan fungsi dan perubahan kemampuan tubuh

Salah satu manifestasi klinis dari stroke yang paling umum terjadi adalah kelemahan alat gerak. Dimanb. kelemahan alat gerak ini berdampak pada penurunan fungsi dan kemampuannya. Diantaranya penurunan fungsi alat gerak, perubahan kemampuan tubuh dalam berespon, perubahan kemandirian, serta perubahan fungsi dan kualitas seksual.

“.....walaupun hanya berjarak 500 meter dari rumah bapak tapi karena bapak lemah berdiri lama jadi semua susah buk....." (P1)

“.....nah bapak untuk membiasakan tangan kiri ini untuk bergerak biar terlatih juga makanya dengan 2 tangan ini mengangkat gelas....antara tangan kanan dan tangan kiri ini tidak sama terasa panasnya, jadi tangan yang kiri ini kurang berasa panasnya buk...." (P6)
"Kegiatan sehari-hari seperti mandi, berjalan, berpakaian semua dibantu” (P2)

“....kalau biasanya suami yang aktif dengan keadaan suami yang lemah tidak bisa bergerak dengan bebas maka isteri yang harus aktif sekarang...supaya tetap harmonis dan kebutuhan terpenuhi...begitukan buk...itu kan kebutuhan normal ya buk." (P4)

Konflik emosi terhadap perubahan tubuh Konflik emosi yang diungkapkan pasrtisipan diantaranya merasa tidak berharga, malu, sedih, marah, tidak berdaya, bosan dan bingung, khawatir serta putus asa.

“....karena kelemahan ini saya tidak bisa pergi kemana-mana sendiri melakukan kegiatan seperti biasa, sering muncul perasaan tidak berguna..." (P4)

“....sekarang jadi dipapah, aduh buk betulbetul malu rasanya dilihat orang dengan keadaan seperti ini...." (P7)

"Perasaan bapak gimana gitu buk....sedih sekali....tidak bisa melakukan kegiatan sehari-hari seperti dulu....." (P3)

"kalau kita memanggil isteri dan lama baru menyahut dan menghampiri, bapak langsung jadi marah dan setelah itu menetes aja air mata menangis." (P2)

“...saya tidak ingin menyusahkan orang terus, terutama isteri saya tapi saya bingung ga tahu sampai kapan kondisi saya seperti ini...." (P4) 
"Saya merasa tidak hidup buk, saya merasa kehidupan saya sudah berakhir dengan kejadian ini........" (P5)

c. Perubahan aktifitas sosial

Perubahan aktifitas sosial ini meliputi keterbatasan melakukan kontak sosial, tidak mau bersosialisasi dan perubahan peran di masyarakat.

“...gimana mau pergi kesana-kemari dengan kondisi begini.....ya di rumah aja..."(P6)

“....lagian kalau keluar juga malu sama orang, mending di rumah aja...."(P5)

"...otomatis pergaulan kita di masyarakat juga tidak selancar dulu lagi....biasanya kita selalu yang diajak kalau ada kematian, sekarang tidak ada lagi yang mengajak kita......" (P7)

2. Gambaran mekanisme koping yang digunakan dan sumber koping klien kelemahan pasca stroke yang mengalami perubahan citra tubuh

a. Peningkatan kemampuan diri dalam menghadapi perubahan citra tubuh

Berdasarkan data yang didapatkan dari partisipan, ada dua cara yang dilakukan partisipan dalam hal ini yaitu mencari informasi penyakit dan sikap positif untuk sembuh.

“...bapak sering baca-baca koran nyari informasi tentang penyakit bapak ini kalau asal sakit inikan termasuk dari makanan dan beban fikiran buk...."(P2)

“...bapak harus yakin bisa kembali beraktifitas seperti semula, sehingganya bapak kembali semangat dan rutin berobat ke rumah sakit setiap awal bulan"(P3) b. Dukungan eksternal dalam menghadapi perubahan citra tubuh

Partisipan mengungkapkan pengalaman mendapat bantuan lingkungan tentang sumber kekuatan dalam menghadapi kelemahan juga didapat dari luar dirinya. Antara lain dukungan orang yang bermakna sebagai sumber koping (antara lain keluarga dan kerabat) serta material asset (berupa alat bantu mobilisasi dan finansial).

“...Alhamdulillah buk, bapak punya anak dan isteri yang sangat mengerti dengan keadaan bapak ini...." (P3)

“...mereka (teman-teman dan tetangga) selalu memberikan semangat supaya bapak tidak kalah dengan sakit ini...."(P6)

“...untung kami menggunakan jamkesmas jadi biaya tidak seberapa yang harus ditanggung..."(P7)

c. Strategi koping menghadapi perubahan citra tubuh

Berbagai strategi koping yang digunakan oleh partisipan diantaranya ada yang dengan usaha mencari bantuan untuk kesembuhan baik secara herbal alternatif maupun medis, mencari dukungan spiritual, mencari makna kejadian, juga ada dengan penilaian pasif.

"“...jadi ya bapak setiap pagi berjalan sambil menginjak kerikil di depan rumah. Katanya itu bisa membuat kaki bapak lebih cepat kembali sehat." (P2)

“...ke RS saja, terapi 2 kali seminggu dan kontrol 1 kali sebulan..” (P1)

"Ya buk...paling ya bapak menyerahkan semuanya pada Allah, kalau memang ini yang terbaik yang harus dijalani ya dijalani dengan lapang dada.....toh Allah Maha Tahu yang terbaik bagi hambaNya..." (P6)

“...mungkin inilah satu-satunya jalan yang harus bapak lalui supaya bapak 
bisa istirahat....bebas dari rutinitas sehari-hari yang tidak kenal istirahat....itu hikmah dari keadaan ini buk..."(P4)

“...ini semua karena menantu saya itu yang begitu tega ke anak saya sampai saya juga ikut kena getahnya..."(P5)

3. Gambaran kebutuhan dan harapan dukungan yang diperlukan klien stroke saat menghadapi perubahan citra tubuh yang dialaminya

a. Dukungan keluarga terhadap kesembuhan

Tingkat ketergantungan yang tinggi terhadap keluarga dalam melakukan kegiatan sehari-hari membuat partisipan menganggap dukungan keluarga merupakan hal yang sangat dibutuhkan menuju kesembuhan. Perawatan yang telaten dan sikap positif keluarga berdampak besar bagi klien.

“...terhadap keluarga bapak merasakan sekali kelemahan ini sangat merubah keseharian bapak, dukungan kehadiran ibu dan anak selalu mengantar berobat seperti saat ini dan penyemangat dalam menghadapi saat sulit pertama kali merasakan kelemahan ini....."(Pl)

"Kalau terhadap keluarga harapannya jangan sampai ada keluarga yang menelantarkan keluarganya yang seperti bapak ini....karena di saat-saat seperti inilah keluarga sangat berarti bagi kita....kalau lagi senang jangankan keluarga buk, oranglain aja bisa jadi keluarga terhadap kita...tapi kalau lagi sakit seperti ini kesabaran keluarga benar-benar diuji buk......."(P6)

b. Harapan pemulihan kondisi tubuh
Harapan mendapatkan pelayanan yang lebih baik dari petugas kesehatan dan harapannya terhadap diri sendiri merupakan harapan yang ditujukan untuk pemulihan tubuh. Pelayanan petugas kesehatan berupa memperoleh informasi edukasi mengenai panyakit dan harapan terhadap meningkatnya sikap caring diungkapkan partisipan sebagai hal yang penting dalam pemulihan. Sedangkan terhadap diri sendiri partisipan memiliki keinginan sembuh dan kembali bekerja.

"kalau petugas kesehatan dukungannya supaya pasien seperti bapak diberi penjelasan tentang penyakitnya biar jadi tahu lebih banyak...."(P1)

"...Bapak ingin cepat kembali seperti semula, tidak menyusahkan lagi..."(P2)

"Kalau harapan ditanya buk ...bapak ingin bisa melakukan semua pekerjaan yang biasa bapak lakukan lagi...."(P6)

Tema penurunan fungsi dan perubahan kemampuan tubuh

Sesuai hasil penelitian Kwon (2006) terhadap 151 pasien stroke yang masih menjalani rawat jalan, bahwa $50 \%$ partisipan mengalami gangguan alat gerak dan 12 orang mengalami mati rasa. Begitu juga penelitian Ratnasari (2012) didapatkan 95\% mengalami tingkat ketergantungan, dimana $30 \%$ dengan ketergantungan sebagian, $45 \%$ sangat tergantung dan 20\% ketergantungan total. Sjogren,et al (1983) dalam Daniel, et al (2009) mengenai aktifitas seksual pada pasien stroke didapatkan bahwasanya terjadi penurunan dorongan seksual, frekuensi hubungan dan durasi foreplay serta hubungan seksual yang nyata.

Tema konflik emosi terhadap perubahan tubuh

Sejalan dengan hasil penelitian kualitatif oleh Kariasa, dkk (2009) yang juga mengidentifikasi respon psikologis yang beragam pada klien stroke diantaranya malu, marah, sedih. Kondisi psikologis yang juga umum dialami oleh individu dengan stroke 
ini dapat berupa labilitas emosional, bermusuhan, frustasi, dendam dan kurang kerjasama (Smeltzer \& Bare, 2008). Easton, Hafsteinsdottir \& Grypdonck (1997) dalam Brauer, Schmidt \& Pearson, (2001) juga mengungkapkan adanya frustasi yang persisten, marah dan depresi yang muncul pada pasien stroke. Hal ini terbentuk sebagai akibat akumulasi rasa sejahtera yang tidak tercapai dan kondisi yang tidak lagi utuh.

Kelemahan sebagai bentuk kehilangan aspek diri yang nyata atau actual loss. Sebagaimana teori kehilangan Kubbler Ross (1969) bahwa setiap kehilangan akan menimbulkan berbagai proses tahapan respon dari individu yang bersangkutan, yaitu denial, angry, bargaining, depression dan acceptance. Respon kehilangan yang tidak ditangani dengan baik akan menimbulkan perasaan berduka dan kehilangan yang berkepanjangan. Akibat lanjutnya akan beresiko menimbulkan berduka disfungsional. Hal ini perlu mendapatkan perhatian dalam memberikan asuhan keperawatan.

\section{Tema perubahan aktifitas sosial}

Hal ini senada dengan penelitian kualitatif Handayani dan Dewi (2009) bahwa pasien pasca stroke aktifitas sosialnya menjadi berkurang, bahkan ada yang sudah tidak pernah lagi keluar rumah untuk mengikuti kegiatan sosial kemasyarakatan. Begitu juga dengan hasil studi Niemi, et al (1988) dalam Daniel,et al (2009) juga melaporkan bahwa stroke memiliki konsekuensi terhadap kegiatan sosial dimana terjadi kerusakan atau penurunan pada aktifitas sosialnya. Penelitian lainnya oleh Salter, et al (2008) yang senada dengan hasil penelitian ini juga mengungkapkan bahwa isolasi sosial sebagai salah satu tema dalam penelitian kualitatifnya.

Pada penelitian ini klien stroke rasa malu dengan perubahan kondisi tubuhnya membuatnya enggan untuk keluar rumah, tidak mau bertemu dengan orang lain. Juga keterbatasan dalam mobilisasi membuat klien merasa untuk bergerak memerlukan usaha yang sangat besar. Hal ini membuat pasien stroke menarik diri dari kehidupan sosial. Hal ini perlu ditindaklanjuti oleh kita sebagai perawat untuk memulihkan fungsi sosial klien.

Tema peningkatan kemampuan diri dalam menghadapi perubahan citra tubuh Hal ini sesuai dengan paparan Pallesen (2012) bahwasanya dengan pendekatan optimis pada diri sendiri untuk hidup dapat menyebabkan individu meningkatkan pembelajaran lanjutan tentang kemampuan dan keterbatasan, untuk pengembangan keterampilan baru dan penciptaan dari identitas diri yang baru setelah stroke. Sehingga kemampuan diri meningkat seiring dengan peningkatan pemulihan.

Tema dukungan eksternal dalam menghadapi perubahan citra tubuh

Hasil penelitian sesuai dengan penelitian kualitatif Wurtiningsih (2012) bahwa dukungan yang diberikan keluarga dapat berupa dukungan informasional, emosional, instrumental dan penghargaan. Walaupun tidak semua dukungan ini teridentifikasi dari partisipan pada penelitian ini, yaitu dukungan informasional, tetapi tiga dari empat tema dukungan keluarga ini terdapat dalam penelitian ini. dimana dukungan emosional diperoleh dengan sikap keluarga, dukungan instrumental diperoleh dengan mengantar saat berobat atau terapi, penghargaan diberikan dengan menunjukkan sikap keluarga yang merawat klien stroke dengan sebaiknya.

Sesuai dengan falsafah gotong royong, saling mendukung di saat ada yang kesusahan dapat mempererat tali persaudaraan. Begitu juga dengan klien kelemahan akibat stroke ini, dengan adanya dukungan dari kerabat sekitar dapat meminimalisir kondisi beban yang dirasakannya. Ketersediaan dan pemanfaatan materi ataupun sarana yang ada disekitar partisipan dapat merupakan faktor pendukung atau support system dapat meningkatkan motivasi partisipan menuju pemulihan.

Tema strategi koping menghadapi perubahan citra tubuh 
Pengalaman partisipan dalam menghadapi perubahan citra tubuhnya diantaranya dengan usaha mencari bantuan untuk kesembuhan baik itu upaya herbal alternatif ataupun medis, mencari dukungan spiritual, mencari makna kejadian dan penilaian pasif. Sebuah penelitian kualitatif yang dilakukan Sibbritt, et al, (2012) di Thailand terhadap pasien stroke menunjukkan bahwa penggunaan rejimen pengobatan multimodal melibatkan pijat tradisional Thailand, pengobatan herbal dan terapi fisik dapat meningkatkan rehabilitasi pasien stroke. Hal ini senada dengan penelitian yang dilakukan oleh Maclean, et al (2000) mengenai terapi rehabilitatif yang diikuti oleh pasien stroke di rumah sakit menunjukkan bahwa salah satu motivasi partisipan mengikuti program pengobatan medis ingin mampu berjalan kembali.

Sesuai dengan penelitian Smith (2002) bahwa peristiwa kehidupan yang sulit seperti stroke dapat mendorong pasien untuk menguji kembali aspek-aspek spiritual dari kehidupan, dan tantangan terkai stroke dapat meningkatkan pertumbuhan dan perkembangan rohani. Karena pengalaman yang mengubah hidup pasien stroke, praktek-praktek spiritual dapat membantu pasien dalam menemukan makna dan keutuhan melalui keyakinan yang mereka miliki. Strategi koping aktif dan positif reframing paling sering digunakan pasien dengan stroke meurut penelitian Gillen (2006) terhadap 16 orang pasien stroke.

Penilaian pasif sebagai strategi koping yang dilakukan partisipan yaitu sikap pesimis, kepasrahan diri, menarik diri dan menyalahkan orang lain. Penggunaan strategi koping sesuai dengan hasil penelitian ini terlihat bahwa masih ada partisipan yang menggunakan mekanisme koping emotional focused. Mekanisme koping emotional focused merupakan strategi koping yang digunakan untuk mengurangi tekanan emosional (Stuart, 2009). Hal ini berarti bahwa strategi koping ini bukan menyelesaikan masalah tetapi hanya mengurangi tekanan emosional, dimana hanya efektif untuk penggunaan yang sifatnya semantara atau jangka pendek. Bila penggunaannya dalam waktu cukup lama akan dapat menimbulkan perilaku maladaptif, yang beresiko timbulnya masalah psikososial pada diri orang tersebut.

\section{Tema dukungan keluarga terhadap}

kesembuhan

Penelitian oleh Mant, et al (2004) menyatakan bahwa dukungan keluarga sangatlah efektif bagi pasien pasca stroke untuk melakukan perawatan di rumah. Hal ini senada dengan penelitian yang dilakukan oleh Teraoka (1992) bahwa keterlibatan keluarga sangat penting pada pasien stroke karena perawatan pasien stroke lebih banyak dan lebih lama dilakukan di rumah. Pemulihan pasien secara langsung berkaitan dengan kemampuan perawatan yang diberikan oleh keluarga. Sehingga keluarga perlu mendapatkan informasi dan edukasi terkait kondisi kelemahan pasca stroke ini.

Tema harapan pemulihan kondisi tubuh

Hasil penelitian ini menggambarkan partisipan berharap mendapatkan pelayanan yang lebih baik dari petugas kesehatan, baik berupa memperoleh informasi dan edukasi tentang penyakitnya dan harapan terhadap meningkatnya sikap caring. Sedangkan harapan partisipan terhadap dirinya sendiri yaitu keinginan sembuh dan keinginan kembali bekerja.

Perawat sebagai pemberi pelayanan kesehatan perlu untuk menyadari persepsi pasien pasca stroke terhadap keinginannya untuk pulih, untuk menginformasikan tentang bagaimana perawatan pasien tersebut, serta memberikan pendidikan dan konsultasi terhadap pasien. Perawat memiliki kesempatan untuk terlibat dengan pasien dari awal terjadinya serangan stroke untuk pengembalian kondisi pasien, membantu pasien untuk mendapatkan kembali kemerdekaan dan kembali ke kehidupan yang bermakna (Hartigan, et al, 2010).

Sejalan dengan penelitian kualitatif Tutton,et al (2012) di Inggris diidentifikasi empat tema, yang salah satu diantaranya adalah harapan untuk pemulihan. Harapan itu 
diungkapkan partisipan sebagai keinginan yang kuat untuk sembuh, kembali normal.

\section{KESIMPULAN DAN SARAN}

Terdapat delapan tema untuk menjawab tiga tujuan khusus pada penelitian ini. Delapan tema tersebut adalah 1) penurunan fungsi dan perubahan kemampuan tubuh 2) konflik emosi terhadap perubahan tubuh 3) perubahan aktifitas sosial 4) peningkatan kemampuan diri dalam menghadapi perubahan citra tubuh 5) dukungan eksternal dalam menghadapi perubahan citra tubuh 6) strategi koping menghadapi perubahan citra tubuh 7) dukungan keluarga terhadap kesembuhan 8) harapan terhadap pemulihan kondisi tubuh.

Respon psikososial yang diungkapkan partisipan menunjukkan perlunya intervensi focus psikososial sebagai perawat jiwa. Sehingga dapat diberikan intervensi seperti meningkatkan aspek positif yang dimilikinya pada klien pasca stroke dengan harga diri rendah dan terapi spesialis berupa cognitive therapy dan cognitive behavior therapy. Berdasarkan perubahan aktifitas sosial yang dialami perlu membentuk self help group pada kelompok pasca stroke yang melakukan pengobatan rutin ke rumah sakit setiap bulannya. Dimana kelompok ini nantinya dapat menjadi sarana untuk berhubungan sosial dan saling memberikan dukungan, pengalaman koping dalam menghadapi perubahan citra tubuh yang dialaminya. Petugas kesehatan khususnya perawat perlu memberikan komunikasi informasi edukasi (KIE) terkait dengan masalah kelemahan yang dialami klien pasca stroke serta perlunya petugas kesehatan lebih mengoptimalkan perannya dengan sikap caring sebagai pemberi layanan kesehatan. Bagi peneliti selanjutnya dapat dilakukan penelitian kuantitatif terkait dukungan keluarga dan kualitatif terkait pengalaman manajemen beban yang dilakukan keluarga.

\section{DAFTAR PUSTAKA}

Brauer, D.J., Schmidt, B.J., \& Pearson, V. (2001). A framework for care during the stroke experience. Proquest nursing \& Hllied Health source rehabilitation nursing, 24 (3). 88-93.

Daniel, K., Charles, D.A., Wolfe, MD., Markus, A., Busch, M.D., Christopher, M. (2009). What Are the Social Consequences of Stroke for Working-Aged Adults? A Systematic Review. Journal of American Heart Association. 40: 431-440.

Departemen Kesehatan RI. (2008). Laporan Nasional 2007: Riset kesehatan dasar tahun 2007. Jakarta: Badan Penelitian dan Pengembangan Kesehatan Depkes RI.

Gillen. G., (2006). Coping During Inpatient Stroke Rehabilitation: An Exploratory Study. American Journal of Occupational Therapy. March/April 2006 vol. 60 no. $2: 136-145$

Handayani, D.Y., \& Dewi, D.E. (2009). Analisa kualitas hidup penderita dan keluarga pasca serangan stroke (dengan gejala sisa). Purwokerto: Universitas Muhammadiyah. Tidak dipublikasikan

Hartigan, I., O'Connell, E., McCarthy, G., O'Mahony, D., (2011). First time stroke survivors' perceptions of their health status and their goals for recovery. International Journal of Nursing and Midwifery. Vol. 3(1), pp. 22-29.

Kariasa, I. M., dkk (2009). Persepsi pasien pasca serangan stroke terhadap kualitas hidupnya dalam perspektif asuhan keperawatan. $\quad$ FIKUI. Tidak dipublikasikan

Keppel, C. C., \& Crowe, S. F. (2000). Changes to Body Image and Self-esteem following Stroke in Young Adults. Neuropsychological Rehabilitation: An International Journal, 10 (1).

Kwon, S.C., Choi, J.M., Kwon, S.U., Kang, D.W., \& Kim, J.S. (2006). Factors that Affect the Quality of Life at 3 Years Post-Stroke. Journal Clinical Neurologi, 2(1): 34-41.

Maclean, N., Pound, P., Wolfe, C., Rudd, A., (2000). Qualitative analysis of stroke 
patients motivation for rehabilitation. BMJ ;321:1051

Mulyatsih, E. (2008). Petunjuk perawatan pasien pasca stroke di rumah. Jakarta: Balai penerbit FKUI

Pallesen, H. (2012). Body, coping and selfidentity, A qualitative 5-year follow-up study of stroke. Jurnal Disability and Rehabilitation.

Polit \& Beck. (2006). Essentials of Nursing research: Methods, appraisal, and utilization. $6^{\text {th }}$ edition, Philadelphia; Lippincott Williams \& Wilkins.

Ratnasari, Pepy (2012). Hubungan antara tingkat ketergantungan activity daily living dengan depresi pada pasien stroke di RSUD Tugurejo Semarang. Semarang: Stikes Telogorejo. Tidak dipublikasikan

Salter, K., Hellings, C., Foley, N., Teasell, R., (2008). The experience of living with stroke: a qualitative meta-synthesis. Journal Rehabilitation Medicine. 40: 595-602.

Sibbritt, D., Pamela, R., Dedkhard, S., Srithong, K., (2012). Rehabilitation of stroke patients using traditional Thai massage, herbal treatments and physical therapies. Journal of Chinese Integrative Medicine: Volume 10

Smith, GR., (2002). Prayer after Stroke Its Relationship to Quality of Life. Journal of holistic Nursing. Vol 20 no. 4: 352366.

Stuart, G.W. (2009). Principles and Practice of Psychiatric Nursing. $9^{\text {th }}$ ed. Missouri: Mosby Elsevier

Teraoka, J., (1992). Family Support and Stroke Rehabilitation. The Western Journal of Medicine

Wurtiningsih, B., (2012). Dukungan keluarga pada pasien stroke di ruang saraf RSUP Dr Kariadi Semarang. Medica Hospitalia. Vol 1 (1). 57-59 